\title{
Many ways to God, many ways to salvation (A conversation on Isaiah 56:1-8 with Islamic tradition)
}

\begin{tabular}{|c|c|}
\hline $\begin{array}{l}\text { Author: } \\
\text { Syafa'atun Aln }\end{array}$ & irzanah ${ }^{1,2}$ (1) \\
\hline $\begin{array}{l}\text { Affiliations: } \\
{ }^{1} \text { Department } \\
\text { Islamic Studie } \\
\text { Theology and } \\
\text { Thought, Stat } \\
\text { University Sur } \\
\text { Yogyakarta, Yc } \\
\text { Indonesia }\end{array}$ & $\begin{array}{l}\text { f Religious and } \\
\text { s, Faculty of } \\
\text { Islamic } \\
\text { Islamic } \\
\text { an Kalijaga } \\
\text { gyakarta, }\end{array}$ \\
\hline $\begin{array}{l}{ }^{2} \text { Department } \\
\text { and Historical } \\
\text { Faculty of The } \\
\text { Religion, Univ } \\
\text { Pretoria, Pret } \\
\text { South Africa }\end{array}$ & $\begin{array}{l}\text { f Systematic } \\
\text { Theology, } \\
\text { ology and } \\
\text { ersity of } \\
\text { ria, }\end{array}$ \\
\hline $\begin{array}{l}\text { Correspondin } \\
\text { Syafa'atun Aln } \\
\text { shafaelmirzan }\end{array}$ & $\begin{array}{l}\text { g author: } \\
\text { irzanah, } \\
\text { a@gmail.com }\end{array}$ \\
\hline $\begin{array}{l}\text { Dates: } \\
\text { Received: } 03 \text { J } \\
\text { Accepted: } 17 \\
\text { Published: } 09\end{array}$ & $\begin{array}{l}\text { uly } 2020 \\
\text { Nov. } 2020 \\
\text { Mar. } 2021\end{array}$ \\
\hline $\begin{array}{l}\text { How to cite th } \\
\text { Almirzanah, } \\
\text { ways to God, } \\
\text { salvation (A cc } \\
\text { Isaiah } 56: 1-8 \\
\text { tradition)', HT } \\
\text { Studies/Theol } \\
77(2) \text {, a6231. } \\
\text { org/10.4102/I }\end{array}$ & $\begin{array}{l}\text { is article: } \\
\text {,2021, 'Many } \\
\text { nany ways to } \\
\text { nnversation on } \\
\text { with Islamic } \\
\text { S Teologiese } \\
\text { ggical Studies } \\
\text { https://doi. } \\
\text { its.v77i2.6231 }\end{array}$ \\
\hline $\begin{array}{l}\text { Copyright: } \\
\text { (C) 2021. The } \\
\text { Licensee: AOS } \\
\text { is licensed un } \\
\text { Creative Comr } \\
\text { Attribution Lic }\end{array}$ & $\begin{array}{l}\text { uthors. } \\
\text { S. This work } \\
\text { ler the } \\
\text { nons } \\
\text { ense. }\end{array}$ \\
\hline Read online: & \\
\hline 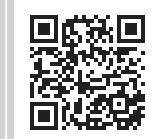 & $\begin{array}{l}\text { Scan this QR } \\
\text { code with your } \\
\text { smart phone or } \\
\text { mobile device } \\
\text { to read online. }\end{array}$ \\
\hline
\end{tabular}

Salvation is the objective of every religious tradition. Christian tradition claims Jesus as the particular redeemer, as he is viewed as the only one who reveals God, truly and fully. Thus, Jesus can be seen as the only way to Salvation. The question then arises, what about other people who do not follow Jesus, instead they follow prophet Muhammad or some other religious figures whom they believe that God has sent to save them? How then, the relationship between Christianity and other religions? By the study on Isaiah, this article is an interreligious conversation on the problem of salvation both in Christianity and Islam. One of the theological points of Isaiah is salvation, and it is also the Christian message. Isaiah is analysed from a hermeneutical approach and then the Qur'anic perspective is presented in conversation with Isaiah.

Contribution: This article speaks for multidiscipline, inter-discipline and transdisciplinary approaches of religious studies in the global theological field. From a multidisciplinary theological perspective, it reflects on the textual and hermeneutical studies within the Abrahamic religions as revealed in the Judaistic scriptures, the Old and New Testament, and the Qur'an.

Keywords: salvation; Christianity; Islam; Isaiah; Qur'an; dialogue.

\section{Introduction}

\section{Why interfaith dialogue?}

Amongst the most exciting and notable aspect of spiritual development in the 20th century is the encounter between religions, which is called an interfaith dialogue. It has become the topic of the day in all arenas. This phenomenon emerges as a result of many factors. The 'crisis of modernity' can be one of them (Kepel 1993:191).

With the exclusion of the particular group that renounces the act of forging relationships of understanding and trust between people of different faiths (i.e., the aim and stuff of 'dialogue'), a substantial number of people assume that the vigour and nature of interfaith dialogue are going to be increased in the future. Thus, today, there is almost no discussion on the issue of urgency of the dialogue and more on what is the most appropriate way for the dialogue, and how it can produce changes for the better in praxis as well as consciousness both at the grass roots and amongst the academics and the intellectuals.

In the recent world, plurality is a verifiable reality, either in an international level or in a national or regional level. Theologically, this is because of the various natures of how God revealed Godself and on the way humans react to it within their variety of cultures and historical contexts. The Holiness Paul John II mentioned in his speech, 'Religions are many and varied and they reflect the desire of men and women throughout the ages to enter into relationship with the Absolute Being' (John Paul Second 1986:2). Many people also say that, in the current situation, different religious communities and individuals are in their close relationship, interdependent on each other. Moreover, I could argue that the existence of interfaith movement means that the world's religions today are interacting on an exceptional scale.

Plurality of religion is not only about the historical past but also about the current reality. This can be seen in the curiosity about other religious tradition by studying them in many possibilities, reading and understanding each other's scriptures. When we do so, it is very often that we are inspired by each other's visions and forms of expression. It is not unusual to find that our different traditions share many of the same fundamental ethics that each of us care about deeply in our own

Note: Special Collection: Scholarly Voices, sub-edited by Yolanda Dreyer (University of Pretoria). 
religions, even though they may be articulated in different ways. When this happens, we can say that to be religious today is to be inter-religious. Friedrich Max Muller, a founder of the modern discipline of the history of religions, wrote, 'He who knows one religion knows none'. Even though he was referring to people who wished to specialise on the issue of a specific spiritual tradition, however, in the current situation, this statement bears an important implication over and above the bounds of religious scholars' societies. In the context where society becomes increasingly plural, the statement can mean that a negligence to multiculturalism can be seen as doing self-marginalisation. It also suggests that by ignoring the neighbour's faith, religious people staying within diverse societies are unable to comprehend themselves.

A person is enriched through encounter and dialogue. When one 'shares' the experience of others, one is challenged to see things as others and experience them. In the book To Kill a Mockingbird, by Harper Lee (1982), this challenge is reflected in Atticus' advice to his daughter's complaints about her day in school saying, 'you never really understand a person until you consider things from his point of view ... until you climb into his skin and walk around in it' (Lee 1982:29-30). Although we can never understand each other completely, we can still understand a great deal about each other.

Dialogue is the learning of truths attained by others and coming back with those truths to enrich our own spirituality. It is called 'passing over' from one religion and way of life to another religion, which may differ from our own religion. Then, we 'come back', enriched by new knowledge and perspectives, not only adapted from other religious perspectives but also beneficial for developing our own religious perspective: Coming back with a new horizon enriched by others (Dunne 1972:xiv). Learning from other religions, not to be like others but to 'come back' to understand our own faith in a new way, is the goal.

Theological and spiritual dialogue will be more valuable only if accompanied by the courage of the participants to question and criticise themselves when encountered by the core of religious experiences of others. An encounter with other religions does not mean that a person sinks inside forever, forgetting to go out and back to his or her own religion. Nevertheless, as already mentioned, this 'passing over' from one culture to other cultures, from one way of life to other ways of life, should be followed by the process called 'coming back' with a new horizon to our own culture, our way of life and our own religion. This is what we call 'spiritual pilgrimage'. Thus, 'passing over' here means the courage to undertake the spiritual pilgrimage to other religions (wonderland) and to 'come back' from the pilgrimage to our own religion (motherland) with a new perspective to enrich our own religion. 'A creative dialogue is also possible only if there is a complete openness, and no preliminary assumption that one revelation . . . must be the yardstick for all others' (Macquarrie 1964:43-44).

\section{The focus of the study}

By studying Isaiah, this article initiates an interreligious discussion on the issue of salvation both in Christianity and Islam. Every religion has salvation as its objective. 'Salvation is a key notion in every religious consideration' (Eminyan 1973:1). One of the theological points of Isaiah is salvation, same as the Christian message. It is said that 'Salvation is a gift of grace that humans do not deserve and cannot earn' (McKenna 1994:563).

\section{Isaiah 56:1-8 (A universal salvation)}

Thus, says the Lord: 'Keep justice, and do righteousness, for soon my salvation will come, and my deliverance be revealed. Blessed is the man who does this, and the son of man who holds it fast, who keeps the Sabbath, not profaning it, and keeps his hand from doing any evil'. Let not the foreigner who has joined himself to the Lord say, 'The Lord will surely separate me from his people'; and let not the eunuch say, 'Behold, I am a dry tree'. For thus says the Lord: 'To the eunuchs who keep my Sabbaths, who choose the things that please me and hold fast my covenant, I will give in my house and within my walls a monument and a name better than sons and daughters; I will give them an everlasting name which shall not be cut off'. 'And the foreigners who join themselves to the Lord, to minister to him, to love the name of the Lord, and to be his servants, everyone who keeps the Sabbath, and does not profane it, and holds fast my covenant - these I will bring to my holy mountain, and make them joyful in my house of prayer; their burnt offerings and their sacrifices will be accepted on my altar; for my house shall be called a house of prayer for all peoples. Thus, says the Lord God, who gathers the outcasts of Israel, I will gather yet others to him besides those already gathered'. (Isaiah 56:1-8)

\section{Contexts}

The Absolute, which is called God, will never reveal Godself in a vacuum. When God revealed Godself, or when the verse is revealed, it is always in a context. Thus, when God revealed Godself to Israel, God intended for very special times and conditions. God's word:

$[W]$ as spoken into the communities of an ancient people who inhabited the Palestinian land bridge between Asia and Egypt during the first millennium B.C. Through the Prophets, God dealt with the realities of Israel's day-to-day living. (Achtemeier 1982:9)

Isaiah addressed his sermon to the people in a very small community. Most of them were the downtrodden, the exploited and the untouchable, who had no control or position within their larger community. In this community, some may have been strangers and castrated men, yet without doubt they considered themselves as the original Israelites, who were 'righteous, chosen, the true servants of Yahweh, his holy people' (Achtemeier 1982:17).

\section{The Author and the dating of Isaiah 56-66}

The scholars do not know for sure who wrote Isaiah 56-66. Yet, they now stand by the bible. The dating of Isaiah 56 , the verses that I discuss here, varies. Clinton E. Hammock summarised this array of dates in his article, by referring to 
the previous author. For example, according to Whybray, the Third Isaiah, including 56:1-8, soon after the return, is possibly dated around 520 B.C.E.; whilst Westermann, 1969: 305 sees Isaiah 58: 1-8 (along with 66:18-24) as a later addition to the Third Isaiah. In this case, Whybray does not agree with Westermann's theory saying that some of the texts were supplemented apparently before and after the main body (chapter 60-62) for they were considered to be too schematic. For this case, Clinton notes that if Westermann' theory is accurate, then Isaiah 56:1-8 and 66:18-24 might be dated to a time period later than the body material (Hammock 2000:46-57).

\section{Content and structure of chapters 56-66}

The Book of Isaiah, chapters 56-66 is more problematic than the preceding chapters. Additional examination and analysis of the relationship between these chapters and the earlier chapters are needed. Paul Hanson (1988) and Elizabeth Achtemeier have done a very thorough analysis of the Third Isaiah, but they did not deal with the relation of the Third Isaiah with the Second Isaiah. Brueggemann suggests that there is a different relationship between the Third Isaiah (chapters 56-66) with chapters 40-55:

It is Second Isaiah which makes Third Isaiah possible. If Second Isaiah is about the public embrace of pain as the way to return to the old stories, then Third Isaiah may reflect the result of this. (Brueggemann 1984:99)

Furthermore, he concludes that all segments of the tradition of Isaiah are 'dynamically related to each other' (Brueggemann 1984:102; cf. Smart 1965).

It is implausible that the chapters 56-66 and 40-55 come from the same prophetic author and yet, current study of chapters 56-66 seems to inspire awareness of the fact that these chapters are correspondent to chapters 40-55. However, those are accurately ordered to a period late sixth to early fifth centuries BC: the time when - under the Persian imperial supervision - the restoration of religious and political life was taking place (Clements 1982:123).

A.S. Herbert, a scholar who accepts the theory of more than one Isaiah, is nevertheless filled with surprise at the similarity of literary style between chapters 56-69 and the earlier chapters written by First Isaiah when he concedes, 'There is much in this section which recalls the language of the eighthcentury prophets' (McKenna 1994:564).

There is also a literary-critical analysis that shows that the contents of chapters $40-55$ have to be attributed entirely to the period of Babylonian captivity in the sixth century BC and the content of chapters 56-66 come after (Clements 1982:118). Nevertheless, there is 'a general agreement that chapters 56-66 were composed in Palestine' (Skinner \& Elmslie 1946:xix).

\section{Theological themes or issues}

The main idea of Isaiah is that Yahweh is the Holy One for Israel. 'The focal point of the call of Isaiah is the holiness of
God' (Motyer 1993:17). It is the same with the Third Isaiah. The Third Isaiah does not use a lot of the word holy, but it introduces a fundamentally identical depiction of the Absolute Reality. The chapters of the Book of Isaiah 56:1-8 describe the people in the gathering that all are one, all are similar and all are welcome in the house of prayer. This oneness, equality and welcoming attitude is attained by preserving justice, devotion to a sinless life, observing Sabbath and preventing evil. The ethical element echoed in the First Isaiah has returned to the place of prominence in the Third Isaiah. 'Isaiah of Jerusalem was a constant critic of his people's sins' (Roberts 1982:134). Nevertheless:

Isaiah is not inviting people to seek salvation by their own works of righteousness but urging those who belong to the Lord to devote themselves to the life that reflect what he has revealed to be right. (Motyer 1993:464)

\section{The strangers and the castrated men}

The article is discussing the verses on the pronouncement of salvation for strangers and the castrated. 'Foreigners' means people who are different and unknown to us, and we may feel suspicious of. Eunuch generally refers to a man who has been castrated and usually made to work as a servant. In Jewish society, eunuchs are considered to be a disgrace because of their inability to bear children. It is said in Deuteronomy chapter 23 , verse 1 , 'He who is emasculated by crushing or mutilation shall not enter congregation of the Lord'. By the above code, a eunuch or a castrated person was excluded from the congregation. 'The prophet's protest is perhaps directed against the application of the rule to persons who had suffered involuntary mutilation' (Skinner \& Elmslie 1946:84).

Contrary to the above code, Isaiah says that there is only one qualification to participate in the society of believers, that is, steadfastness to the religion, practices and ethical principles. In this case eunuchs and the castrated can participate and will have place in the Temple. The eunuchs and strangers will not be excluded and have their places to worship in the Temple. All the people in the Temple, thus, can share the blessing of Israel's covenant with them. 'Eunuchs represent all of the outcasts who will be gathered into the new community of faith' (McKenna 1994:570).

Basically, the Third Isaiah views salvation as nationalistic, but Isaiah Chapter 56:7 introduces the audiences to a principle that is universalistic, where God's Temple will become a temple for all peoples.

In this case, especially Verse 2 is very inclusive, it embraces the strangers and the castrated which used to be considered as outcast people. The verse also shows that God's grace is unlimited, and the Old Testament has never been exclusivist on the basis of nationalistic divides.

By reading Isaiah, we can see that God sees far into the future and says in the most illuminated and radical statement, 'for My house shall be called a house of prayer for all nations' (v.7b). What is inferred in the verse is that the messenger of 
God promotes the essence of religious universalism, where Jerusalem Temple is considered to be the House of God for all nations, and thus, it must be open to people of all religions and not just the Jews. Indeed, it is essential that overcoming barriers between believers needs to be done for the survival of human being, it is beyond moral imperative only.

The strangers and the castrated men are welcome to the holy mountain, where they can find God. They are not only allowed but God himself also will guide and accompany them just as any other believer of Israelite. God's House of prayer will be the place where they will feel happy and joyful, as their burnt offerings and sacrifices will be accepted (v. 7).

\section{Preconditions for salvation: carry justice and devotion to a sinless life}

According to the verses, there are preconditions for believers to be admitted to God's Temple, that is, doing justice and devotion to a sinless life, observing the Sabbath and staying out of evil. The verses also say that for Jews and Gentiles to attain salvation, social justice and personal righteousness are needed. Thus, in any age and for any people, spiritual religion will never change. God always asks his children to do social justice and personal righteousness with devotion to a sinless life as their virtues, and both are inseparable. When all are done, salvation will come. 'Obedience is to be lived out as a response to salvation' (Oswatl 1998: 455; Cf. Oswalt 1996).

When the verse mentions righteousness, it is interpreted as moral conduct and submission to God's edicts. Furthermore, it is the correct affiliation with God's covenant which will bring them to love others and lead others to do the same to God.

\section{Observation of the Sabbath and staying away from sinful and immoral behaviour}

The teachings of Isaiah proclaim that happiness is felt when people experience the true blessing of life, which is revealed and disclosed in two performances: not to disrespect the Sabbath and not to commit any evil.

The question is why Sabbath-keeping is promoted in the verse as a fundamental of spirituality? The answer is that, 'keeping of the Sabbath signaled the covenant relationship with God. By giving God a day for rest and worship, we honor God's name and renew our covenant relationship with God' (McKenna 1994:566).

Sabbath-keeping is fundamental. It is assumed that the believer 'prevent themselves from conducting all sinful behavior' (v. 2c). In everyday life, there is a constant allurement to do evil, and thus, being attentive to God's word means self-restraint against allurement to sin. 'The Sabbath is frontline protection against sin' (McKenna 1994:567).

\section{The essentiality of the verse for today's encounter between people of different religions}

The eminent subject of the verses is about salvation, which is the crucial issue in every religious tradition. Salvation constitutes the cause of every religion. The question is who has the right to salvation? Will every believer get salvation or only specific believers? How does Christianity perceive other religious tradition on the subject?

\section{Distinctiveness and exclusiveness in Christianity}

The message of the verse discussed above is about salvation, which is very inclusive. Both, Jews and non-Jews, and even strangers and eunuchs, or the castrated, are included. It is not unusual for foreigners to be suspected, but are not excluded: the verses say that they are welcome in God's Temple.

Nonetheless, there are many examples of the element of exclusiveness of Christianity or Jesus. Timothy 2:5, for example, says that Jesus is the 'only arbiter' between God and human beings, so there is 'no other name' and no one gets salvation without him as a mediator (Acts 4:12); it is only through him that someone can come to the Father (John 14:6). Here, Jesus is considered to be 'the one and only Son of God' (John 1:14), and thus, anyone who sees Jesus sees the Father (John 1:14). No one else but Jesus who reveals God truly and fully. He is the genuine Saviour of the world. The question then is what about all the people who do not believe in those teachings, such as the people who have followed other religious figures?

There are at least three phases in the history of Christian perception of other religious traditions which show the Christians' inclination towards the acceptance of non-Christian religions declaring salvation as the universal will of God.

First, exclusivism: that there is no salvation outside the Church (Race 1983:10-37) is a total disapproval for other religions. This perspective was introduced and proliferated by Karl Barth. The exclusivists believe that there is only one true, saving religion, that is, Christianity. Thus, the doctrine 'Extra Ecclesiam nulla salus', meaning that there is no salvation outside the Church, holds a critical role. Those who are outside Christianity, be they heathens, Turks, Jews, or even false Christians and hypocrites, cannot expect either love or any blessing from God and accordingly remain in eternal wrath and perdition (Hick 1985:66-74, 30-34). This complete insensitivity to other religious traditions, and the steadfast belief in the conversion of non-Christians to Christianity to attain salvation, is the subject of missiology: a branch of theology which, in opposition to the nonChristian religions shows the Christian religion to be the only way, the truth and the life, attempts to deprive the non-Christian religions and to plant in their stead the evangelic faith and the Christian life (Hick \& Knitter 1987:15-17). 
Second, inclusivism: this shows tendencies of Christian thinkers to convince themselves that they have a better understanding of other religious traditions. Karl Rahner (1904-1984) especially promotes this concept, with his 'Anonymous Christian' or 'Unconscious Christianity' in Bonhoeffer's term. This view of the inclusivist theology of religions is described as the notion of Christ implicit within all other faiths; the grace of Christ being a fundamental component for salvation. Since the idea was announced it has provoked enough discussion, evoking both praise and criticism.

Third, pluralism: defining multicultural and multireligious environments and struggles to promote tolerance, harmony and understanding amongst adherents of other religious traditions in creating peaceful conditions. This alternative approach promoted by John Hick shows that non-Christian religions hold the right to salvation as the universal will of God.

Paul Knitter, as one of the proponents of pluralism, argues that Christology was and is evolutionary, which is a continuum of ceaseless interpretation. The language 'one and only' can be questioned as it is the main content of the belief and experience of the early Church (Knitter 1985:182).

Antonie Wessels in his book contends that in fact, Acts 4:12 ('No other name') has nothing to do with the interrelation between Christianity and other religions: it is about comfort ministry for Peter and John. Addressing an inquiry to the problem, on being asked how and with what kind of power did you do healing (Acts 4:7), they responded, 'by the name of Jesus Christ of Nazareth ... And there is no salvation in any other name' (Acts 4:10 \& 12). It can be inferred that it is not an advice about penitence or missionary journey but an advice about a testimony in a court. 'No other name is a witness, a declaration, respecting the name of the one (not Jesus himself, but God) through whom salvation is achieved'. It is a statement of acknowledgment on the way of Jesus and not a remark on the astuteness of some other religion (Wessels 1995:55).

Francis Young gives another approach to the discussion saying that 'one and only' for Jesus belongs 'not to language of philosophy, science, or Dogmatics, but rather to the language of confession and testimony' (Young 1977:13). In this case, the New Testament author uses the language of enthusiastic believers and not of analytic philosophers. Thus, Knitter says that when it describes Jesus as the one and the only', Christians were attempting to develop a personal relationship and a commitment which illustrate the meaning of becoming a community of Jesus and not trying to elaborate a metaphysical principle (Knitter 1985:185).

Some scholars in a pluralistic, Christological approach also use different interpretation for the claim. John Hick, for example, although he has discomposed and made a provocative reassessment of the 'myth of Incarnation', it need not and should not be read as a refusal of the divinity, or the saving power of Jesus. Rather, it should be referred as a way of reinterpreting what it means to call Jesus divine in such a way that Christians can understand the role of Jesus more clearly and follow him more resolutely (Hick 1977: 167-185). Knitter also argues that Christians still keep maintaining and declaring that Jesus alone is divine and the redeemer. The significance of Jesus still can be maintained between many religions in the world, by referring 'Verily, but not only'. For Knitter (1995), theologically:

[T] his means that while Christians can and must continue to announce Jesus of Nazareth as one in whom the reality and saving power of God is incarnate and available, they will also be open to the possibility/probability that there are others whom Christians can recognize as son or daughter of God. Personally, such a pluralistic Christology allows and requires Christian to be committed fully to Christ but at the same time genuinely open to others who may be carrying out similar and equally important roles. Ecclessially, this means that the churches will go forth into the whole world with a message that it universally relevant and urgent, but at the same time will be ready to hear other messages from very different sources that may also be universally meaningful and important. (p. 35, [author's own italics])

One of the serious issues in interfaith dialogue is the dispute about the decisiveness and the distinctiveness of Christ. Is Jesus distinct amongst religious figures in the history? How then Jesus is unique?

Attracted by what Jesus speaks of 'many mansions in God's House of Prayer' in John 14:2 as well as by John 14:6, John Hick in his book Many Mansions said that:

$[T]$ hese verses stand only a few lines away from each other in the same chapter of the same Gospel, but they have traditionally supplied both the dialogic universalist and anti-dialogic particularist with their favorite proof texts. (Cox 1988:10)

To answer his curiosity of the likely incompatible verses, he points out about the teachings of Jesus on doing business in dialogue. In this case, he introduces an approach to the evolution of understanding. For Hick, the interpretation of religious text is in perpetual change: 'To follow Jesus means to deal with specifics, not generalities' (Cox 1988:12). Thus, Hick emphasises how religion will always remain a composite grace:

Jesus, after all, was fiercely opposed by many of the religious people of his day. His attacks on the misuse of religion remind us that, whatever religion exists, we can be sure that someone is trying to use the gods to dominate, frighten, or oppress someone else. (Cox 1988:13)

In as much as the concern about the distinctiveness of Jesus, in his book No Other Name?, Paul Knitter contends that there are many explanations for the concept. Conservative evangelical and mainline Protestant paradigms maintain an exclusive distinctiveness of Jesus by insisting that Jesus is the soul where true revelation is found. This means that the Christ story is crucial for anything in history about the real encounter with God. Dissatisfied with the argument, the Catholics have come up with a more comprehensive model for the distinctiveness of Jesus. For them, God disclosing saving intervention in Jesus accommodates all other religions, 
be it as anonymous as what Rahner says, or others. According to this perspective, Jesus continues to be fundamental, at least normatively for all religious experiences. For Knitter, these conventional assertions are insufficiently sensitive to the way they contradict contemporary awareness of historical relativity and to the way they impede authentic dialogue with believers of other faiths'. Knitter introduces the uniqueness of Jesus in the theocentric model, where his uniqueness is relational. The model says, 'Jesus is unique, but with a uniqueness defined by its ability to relate to - that is, to include and be included by - other unique religious figures'. This perspective declares Jesus as being neither exclusive nor normative. Jesus is always the proper manifestation of divine revelation and salvation (Knitter 1985:172).

The above notion is built on the dominant principle that the texture of human experience about Jesus is evolving, and thus, there is a different statement on Jesus between the time of the codification of the Gospel and past dogmatic. This involves a different 'historical consciousness' that all cultures and historical accomplishment are conditional. Furthermore, there is a new consciousness for pluralism, particularly recognition of the urgency and the demand to create a new pattern for unity amongst peoples. Knitter argues that, 'not to understand Jesus anew in this new texture, not to open oneself to the possibility of a new Christology, is to run the risk of confining the past in an idolatrous "deposit of faith"' (Knitter 1985:173). In mystical tradition, this perspective can be called detachment, which means being aloof, so as not to be confined by anything. Thus, in this case, we are detached from our conceptualisations of the past Christology, lest we fall into idolatry in the name of championing orthodoxy (Almirzanah 2011:184).

To be a Christian means that someone has to pursue Jesus Christ as the Way (immitatio Christi) and by doing this he or she will attain salvation via Jesus, as discussed before. Traditionalists understand it to connote that there will be no salvation without Jesus. But further, that concept changes, even they come to the opinion that church membership is not the guarantee of salvation (Amalados 1990:76-77).

Pursuing Jesus Christ to be the only Way means that someone has to accompany Jesus always and undertakes everything he took and is taking. In this case, orthopraxy has preference over orthodoxy, but both have to be contextually performed. There is an affirmation by Christian community that God's manifestation takes place in Jesus and in the spirit. Nevertheless, there is no mundane manifestation of God (as well as the manifestation of God in Jesus) that can completely absorb God. In addition, the ability to comprehend and receive the incomprehensible God is limited: Deus semper maior.

It is well accepted that 'Jesus is the Lord', yet Matt 7:21 says, 'Not everyone calling me "Lord," "Lord," can come to the Kingdom of Heaven, it is only someone who actually do the will of the Father can enter'. All believers pursue to fulfil the will of the Father; however, not all can accomplish to uncover the will of the Father. In addition, granted that Matt 28 says, 'Baptise'; the discussion is that, despite the fact that absolute conversion is at the root of baptism, we can say that it is inaccurate to assume that baptism is 'a pure spiritual act, because baptism was more "a social-political act"' (Amaladoss 1990:58). History tells us more on the matter. Thus, it can be concluded that if the question of salvation is inherently resting upon personal encounter with God, then all interventions are contingent.

There is another verse which is considered more inclusive: Genesis Chapter 14 is an example. If in Genesis 12:2 we read that Abram was blessed by God and called from Ur to become himself a blessing in Canaan, and this blessing also plays an important role in the story about the meeting between Abram and the king of Salem (Jerusalem), Melchizedek. Genesis14:1-11 describes a war being waged amongst certain kings and the taking of Abram's nephew, Lot as prisoner by the kings of Sodom and Gomorrah. Abram pursued them, defeated the kings and liberated Lot. On his way back, he was received by Melchizedek in a place not far from Jerusalem and offered the bread and wine of hospitality through which peace was established. Abram recognised Melchizedek not only as king but as priest, thereby implying that he, or at least the narrator of the story, acknowledges El as worshiped by Melchizedek to be identical with Jahweh, the same God who led him from Ur of the Chaldees (Genesis 12:1).

Another argument was given concerning the death of Jesus. Did Jesus die for a specific group of people, the elect, or for all people? Fackre and Sanders affirm what is known as unlimited atonement, '... where Jesus died for every single individual, whether non-Christian or Christian'. According to them, the passages speaking of 'world' and 'all' meant that God wants every single individual to benefit from the work of Christ (Fackre, Nash \& Sanders 1995:12).

In Christian tradition, Jesus is considered to be the necessary entry and centre for understanding themselves and also others. Nevertheless, it should also be remembered that the Holy Mystery they acknowledge and call God, is always bigger than the reality and the word of Jesus. There are many possibilities for Christians to see how other religious traditions may have their own perspectives and responses to the Absolute Reality in their own tradition. Knitter (1985) contends that:

[T] hey did not have to be unilaterally 'included' in Christianity. But, all the religions could be, or may need to be included in that is, related to - each other, because all of them keep their efforts to find or be faithful to the inexhaustible Mystery or Truth. (p. 201)

What brings a person to faith in commitment to Jesus is a converting experience. Jesus empowers the heart and illumines the mind such that one can now feel and know and, 
especially, act in an appropriate manner. Indeed, the experience of faith necessarily includes the conviction that Jesus is God's revelation and grace, but it does not necessarily include the conviction that he alone is this revelation and grace. Therefore, as John Macquarrie has urged, one can be totally faithful to Jesus whilst honestly open to the prospect of other salvation. To wit, the essence of the Gospel proclaims that everyone is encountering the wholeness of God in Jesus; thus, everyone is experiencing 'a complete and true manifestation of the fundamental meaning of the authentic human existence' (Tracy 1975:223). Believing in this mystery is not incumbent upon Jesus being the only such manifestation.

\section{Isaiah in conversation with the Qur'an}

The following discussion is about the corresponding spirit between Isaiah and the Qur'an. The Qur'an mentions that God intentionally designed human diversity and pluralism, to encourage them to recognise each other and collaborate amongst them. Implicitly, it is said in the Qur'an:

We (Allah) have created human beings into different peoples and tribes so that you all may get to know, understand and cooperate with each other. The most honorable among you in the sight of Allah are the righteous ones. (the Qur'an 49:13)

The closing verse points out that man and woman both are to be judged by their noble conduct and not by their affiliation to a peculiar national, tribal, religious or other society. Alternative verses in the Qur'an 2:62 and 5:69 say that:

$[B]$ elieve in God and the Last Day, not religious alliance, is the sole criterion of right and wrong, truth and falseness, and deliverance or destruction on the Last Day of Judgment. (the Qur'an 2:62 and 5:69)

In the same manner Isaiah says, the only qualification to be included in the community of believers is loyalty to the spiritual, ritual and ethical requirements. Surely, religion consists of both what is believed and how to live.

Conforming to what Muslims believe, God has sent a great number of prophets, that is, around 124000 prophets in the history of humankind, out of which 315 of them were messengers. It is predicted that all people have to believe in these prophets and messengers, signifying the acceptance of the essential truth in their teaching. It is advised in the Qur'an that human beings have to believe in all the prophets that God has sent to them and affirm that, 'We (God) make no difference between one and another of them and we all submit ourselves to God' (the Qur'an 2:136). The reason for the Qur'an denouncing the proclamation 'Extra ecclesiam nulla sallus' (outside the Church there is no salvation) by the Catholic Church before the Second Vatican Council is that the Qur'an alternatively declares:

[T] those who believe (in the Qur'an) and those who follow the Jewish (Scriptures) and the Christians and Sabians, whoever believe in God and the Last day and work righteousness, will have their reward with their Lord; on them will be no fear nor will they grieve. (the Qur'an 2:62)
Plurality is a factual reality of our extraordinary world, both on an international level and the national level. This plurality is as ancient as the existent of human beings itself. The same set of conflicts is an indispensable component of human experience in diversity. The story of creation in the Qur'an 2:30 states that God announced that he was going to 'place a vicegerent on the earth', to which the angels disagreed, asking 'Will You place on the earth [another being who] will spread corruption and shed blood in it, while we praise and glorify You?' Despite the fact that God replies to them by saying, 'I know what you do not know', the verses reveal that the angels commanded a profound and authentic vision about the future of humanity. On the other hand, throughout the story of Qabil/Cain and Habil/ Abel, the Qur'an 2:30 as well as the Bible/Genesis 4:3-16 show that human beings are the children of a figure (Qabil/ Cain) who commits the transgression of fratricide. The question then is what does God mean when he says that he knows about the predicaments of humanity that the angels do not know? Could it be something related to mankind's comprehension of truth, wisdom and compassion? It might even have been something to do with mankind's ability to repent for an evil that may have been done that was made to appear in a different way. Undoubtedly, the story of the original fratricide appearing in the Qur'an (not mentioned in the Bible) portrays that whilst Qabil/Cain waited to be disposed of by the bird called Raven (al-ghurab), he is crushed with grief and repentance for the terrible evil he has committed (fa asbaha min al-nadimin) and wonders how to bury his brother's naked corpse.

The main Qur'anic meta-narrative on the history of human beings is not about the constantly escalating cruelty, the moral-decline and degeneration; it is about the continuum of God's revelation and guidance delivered to humanity by the ministry of the great prophets and messengers, who exemplified human virtue and perfection and called upon all humanity to accomplish their objectives by honing their lives. The story of Qabil's/Cain's repentance for killing his brother in the Qur'an exhorts the reader to remember that God ordained human legacy to follow the model of Habil/ Abel who chose to face death rather than rebel against God and kill his brother Qabil/Cain (la in basatta ilayya yadaka litaqtulani ma ana bi-basitin yadiyya ilayka li-aqtulaka; inni akhafu Allaha rabba al-alamin), and not the lesson of reciprocal animosity set by Qabil/Cain. As in the case of Adam, what the angels are ignorant about in human beings is that, even though Adam and his children will have the capability to commit big crimes and indulge in corruption, God will continuously guide humanity and gracefully steer their destiny to live in peace and harmony with one another and with all creation.

There are myriad verses of the Qur'an commonly presented to reinforce their conviction, for example the Qur'an's verses 49:13 and 5:48. Nonetheless, the story about Habil/Abel and Qabil/Cain in the Qur'an and the Bible mentioned above strongly emphasises the divine command to be in awe of 
God and embrace human relationship that is not one of conflict, jealousy, hatred, malice, prejudice and crime, but rather one that continuously demonstrates the profound honour and esteem for one's fellow human beings in repugnance of violence of any manner. It is fascinating that the paradigm of peace through conversation and appreciation is as popular in Athens (i.e., Hellenistic philosophy) as it is in Mecca and Jerusalem (i.e., Qur'an and Bible). A pagan story of the death of Socrates uses the same jargon as Habili/Abelian ethics, suggesting nonviolent conversation and appreciation to violent conflict, even at the cost of one's life. Thus, Habil in the Qur'an, Abel in the Bible, and Socrates in Athens, can be considered as martyrs to dialogue, both for those who place themselves in the tradition of the Qur'an and/or the Bible and for those who identify themselves more as humanists with no specific religious membership.

\section{Postscript}

It is obvious that salvation cannot be restricted to a specific group of people, and it is for everybody. Karl Rahner argues that all living things have a place in God's residence, and there are many forms of articulation of human desire to unconditionally submit to God, such as prayers, alms-giving, fasting and any other spiritual discipline (Rahner 1983:34). Karl Rahner promoted a kind of modern theology which deeply influenced the Catholic Church. As an outstanding figure of Vatican, he developed a perspective on Christian attitude towards other religions that carries him as the chief architect of the documents later issued of Vatican II (Vorgrimler 1986:94-102). Rahner maintains that Christianity claims to be the absolute religion intended by God for all and recognises the followers of other faiths as anonymous Christians because of their implicit relation to Christ (Rahner 1966, vol. 5:118-120). Transcendentalism is the most distinctive characteristic of human beings keeping them aligned with God.

God has revealed and embodied himself in various people in their corresponding state of being. All in all, God saves people by way of their own belief whilst his boundless saving power remains omnipresent, operating universally in numerous ways. Christians are saved through Jesus Christ, and thus, Christ is considered the path to Christians' salvation, whilst the correspondent traditions delegate this manifestation to others. Meanwhile, the Qur'an says:

To everyone among you have We (Allah) prescribed a law and an open way (Shir'ah wa Minhaj). If Allah had so willed, Allah would have made you a single people, but Allah's plane is to test you in what Allah had given you, so strive as in a race in all virtue. The goal of you all is to Allah. It is Allah that will show you the truth of the matters in which you argued. (the Qur'an 5:48)

Considering that human beings are exclusive and unique, not generic, and hence, the language and explanation to respond to the word of God (kalam Allah) will be plenty and diverse. Humans' capabilities to comprehend and articulate the absolute reality are diverse and contingent. The glimmer of divine resourcefulness brings to life the virtues of people such that God may be glorified and experienced in countless means (Gittins (ed.) 2000:25). Amidst human civilisations can God's revelation be found in as much multiplicity as culture itself and in the web of human relationships that endorse the existence of culture.

Psalm 65:7 says, 'let all the peoples adore you, O God, let all the people adore you'. In almost the same manner the Qur'an 51:56 says, 'and I (Allah) did not create Jinns and mankind except they should worship Me'. Furthermore the Qur'an 30:22 says:

$[A]$ nd among God's wonders is the creation of the heavens and the earth, and the diversity of your tongues and colors. For in this, behold, there are messages indeed for all who are possessed of innate knowledge.

Thus, it can be inferred from those verses that if mankind was created to worship God, and God created diversity in languages and colour, surely worship also must be in their own languages; in their own ways, as per the customs of their own culture. In our situation, we must ask what is it that people are seeking in their cry in diverse ways to come closer to their God.

In fact, some mystics, such as Ibn al-'Arabi (1165-1240) and Meister Eckhart (c.1260-c.1328), suggest we do not allow to believe that, our beliefs are the end or goal of our journey; instead, we should understand that the realisation of the ubiquitous presence of God is the goal. This resonates with the thought of Abraham Joshua Heschel when he writes:

$[R]$ eligion is a means, not an end. It becomes idolatrous when regarded as an end in itself. ... To equate religion and God is idolatry. ... Does not the all-inclusive of God contradict the exclusiveness of any particular religion? ... Is it not blasphemous to say: I alone have all the truth and the grace, and all those who differ live in darkness, and are abandoned by the grace of God? (Kasimow \& Sherwin [eds.] 1991:14)

The contemporary Christian theologian of religious diversity, Mark Heim, draws out the significance of what is called Trinitarian theology as an insight on the validity of the diversity of religious systems and goals. In the revolutionary book on a 'Trinitarian theology of religious ends', Mark Heim (2001) addresses:

The concept of Trinity contributes to a specific support in confirming the fact and truth of what is different. Trinitarian doctrine eliminates the opinion that amidst the available demanded disclosure of God, the sole restricted strand is authoritative. Trinitarian faith would likewise exclude the perception that most of these disclosures could be compressed to a particular type fundamental to them. A plain exclusivism and a plain pluralism are indefensible. Christians could expect legitimacy in other religions as a consequence of the belief that the concept of Trinity speaks for a universal truth how the way the world and God really are. (p. 127)

In addition, the highly influential Salafi modernist thinker Rashid Rida suggests a different explanation about the 
meaning of the word Islam mentioned in the Qur'an that can be considered as supporting and adding to the perspective discussed on religious pluralism. The Qur'an says, 'is it other than the religion of God they desire, when to Him submitted those within the heavens and earth, willingly or by compulsion' (The Qur'an 3:83). In this verse, the Qur'an applies the word aslama as the fourth form of the root. S-L-M means 'submit or surrender' to God. The word Islam originates from the verbal noun of precisely the same form and in such a way that it means 'submission'. As for the discussion of the Qur'an verse 3:19, Islam is classified as 'the religion of God'. Rida argues that interpreting the word Islam to ascribe to the traditions, doctrines and practices followed by Muslims, is a post-Qur'anic experience to the extent that the word al-din is interpreted in its social and traditional context. This form of Islam, Rida said, '... which [vary] according to the differences that have occurred to its adherents in the way of uncritical acceptance, has no relationship with true islam.' On the contrary, 'it is subversive of true faith' (Rida n. d,.:361 and Esack, 1997:130)

A great mystic master of Bagdad, Abu 1-Qasim Muhammad al-Junayd (d. 910) on one occasion adopted an allegory of water tinted by its vessel as an analogy for unity in diversity, saying 'The color of the water is the color of its container' (Ibn al-'arabi 1972, 1989:316.10 and Chittick 1989:149, 229, 341-344). Referring to this metaphor, it is acceptable to say that similar to every fundamental element of the existing order, all religions originated from God. Thus, Junayd's metaphor can be rephrased and interpreted by arguing that whilst water symbolises the divine Being, diversity of religions is exemplified by the colour, or colours of the vessel. Following the metaphor, we can say that some religions can be monochromatic or homogenous, the colours of which are rigidly limited, or wasted and colourless, whilst others may have more distinct colours, but all having the same essential tint. Again, others may have specific colours of a different chroma, etc. (Almirzanah 2011:111). The above perspective is firmly grounded in the Qur'an, where it says, 'If your Lord had willed [it], $\mathrm{He}$ would have fashioned humanity into one community, but they will not cease to differ, except those upon whom your Lord has been merciful' (the Qur'an 11:118-119).

Considering the universality of religions and their indispensable unity, all plausible variations between religions are yet the external fashions and the typical formulation of the same universal, never-ending, perennial and indescribable truth, for 'what counts at the deepest level in religion is the spirit of faith and not any formal affiliation' (Wahiduddin 1990:3-11). There are many ways to salvation and to God. Every people have their own way. 'The paths to God are numerous as the breaths of the creatures', writes Ibn al- Arabi, a great mystic master of Andalusia 'since the breath emerges from the heart in accordance with the belief of the heart concerning Allah' (Al-'Arabi 1972:III, 411. 22).

\section{Acknowledgements}

The views expressed in this article are those of the author and do not necessarily reflect the position or policy of the Department of Religious and Islamic Studies, Faculty of Theology and Islamic Thought, State Islamic University Sunan Kalijaga Yogyakarta, Yogyakarta, Indonesia and the Department of Systematic and Historical Theology, Faculty of Theology and Religion, University of Pretoria, Pretoria, South Africa.

\section{Competing interests}

The authors have declared that no competing interests exist.

\section{Author's contribution}

S.A. is the sole author of this article.

\section{Ethical considerations}

This article followed all ethical standards for research without direct contact with human or animal subjects.

\section{Funding information}

This research received no specific grant from any funding agency in the public, commercial or not-for-profit sectors.

\section{Data availability}

Data sharing is not applicable to this article as no new data were created or analysed in this study.

\section{Disclaimer}

The views and opinions expressed in this article are those of the authors and do not necessarily reflect the official policy or position of any affiliated agency of the authors.

\section{References}

Achtemeier, E., 1982, The community and message of Isaiah 56-66, Auhgsburg, Minneapolis, MN.

Almirzanah, S., 2011, When mystic masters meet: Towards a new matrix for ChristianMuslim dialogue, Blue Dome Press, Clifton, NJ.

Amaladoss, Michael, 1990, 'Dialogue and Mission, Conflict or Convergence', Making All Things New, Maryknoll, Orbis Books, NY, pp. 43-56.

Brueggemann, W., 1984, 'Unity and dynamic in the Isaiah tradition', Journal for the Study of the Old Testament 29, 89-107. https://doi.org/10.1177/030908928 400902905

Chittick, W., 1989, The Sufi path of knowledge: Ibn al-'Arabi's metaphysics of imagination, State University of New York Press, Albany, NY.

Clements, R.E., 1982, 'The unity of the book of Isaiah', Interpretation 36(2), 117-129. https://doi.org/10.1177/002096438203600202

Cox, H., 1988, Many mansions, a Christian's encounter with other faiths, Beacon Press, Boston, MA

Dunne, J.S., 1978, The way of all the earth, the: Experiments in truth and religion, University of Notre Dame Press, Indiana.

Eminyan, M., 1973, The mystery of salvation, Malta University Press, Malta.

Esack, F., 1997, Qur'an, liberation, and pluralism, an Islamic perspective of interreligious solidarity against oppression, Oneworld, Oxford.

Fackre, G., Nash, R.H. \& Sanders, J., 1995, What about those who have never heard?, Intervarsity Press, Downer's Grove, IL.

Gittins, A.J., (ed.), 2000, Life and Death Matters, The Practice of Inculturation in Africa, Steyler Verlag, Germany. 
Hammock, C.E., 2000, 'Isaiah 56:1-8 and the redefining of the restoration Judean community', Biblical Theology Bulletin 30(2), 46-57. https://doi. org/10.1177/014610790003000202

Hanson, P.D., 1988, 'Third Isaiah: The theological legacy of a struggling community', in C. Seitz (ed.), Reading and preaching the Book of Isaiah, Fortress, Philadelphia, PA pp. 91-103.

Heim, M., 2001, The depth of the riches: A Trinitarian theology of religious ends, William B. Eerdmans, Grand Rapids, MI.

Hick, J. (ed.), 1977, The myth of incarnation, J. Hick (ed.), SCM Press, London.

Hick, J., 1985, God has many names, The Westminster Press, Philadelphia, PA.

Hick, J. \& Knitter, P.F., 1987, The myth of Christian uniqueness: Toward a pluralistic theology of religions, SCM Press, London.

Ibn al-'Arabi, Muhyiddin, 1972, al-Futuhat al-Makkiya, (ed. 'Uthman Yahya), Vol 12 al-Hay'at al-Misriyat al-'Amma li al-Kitab, Cairo. Vol. 12 has date on cover: 1989. Includes bibliographical references and indexes Introduction in Arabic and French.

Kasimow, H. \& Sherwin, B.L. (eds.), 1991, No religion is an Island: Abraham Heschel and interreligious dialogue, Orbis, Maryknoll, New York, NY.

Kepel, G., 1993, The revenge of God: The resurgence of Islam, Christianity and Judaism in the modern world, Penn State University Press, Pennsylvania.

Knitter, P.F., 1981, 'The world religion and the finality of Christ: A critique of Han Kung's on being a Christian', in R.W. Rousseau (ed.), Interreligious dialogue, Ridge Row Press, Scranton Pennsylvania.

Knitter, P.F., 1985, No other name?; a critical survey of Christian attitude toward the world religions, Orbis Books, Maryknoll, New York, NY.

Knitter, P.F., 1995, One Earth, Many Religions: Multifaith Dialogue and Global Responsibility, Orbis Books, The University of Michigan.

Lee, H., 1982, To kill a mockingbird, Warner Books, New York, NY.

Macquarrie, J., 1964, 'Christianity and other faiths', Union Seminary Quarterly Review $20,43-44$.

Motyer, J.A., 1993, The prophecy of Isaiah, Inter-Varsity Press, Westmont, Illinois.

Oswalt, J.N., 1996, 'Key themes in the book of Isaiah: Their relevance for Christian theology', in T.D. Anderson (ed.), The Newell lectureships, vol. 3 pp. 1-90, Warner.
Oswalt, J.N., 1998, The Book of Isaiah, chapter 40-66, William B. Eerdmans Publishing Company, Grand Rapids, MI.

Pope John Paul II, 1986, Address of John Paul to Representatives of the Christian Churches and Ecclessial Communities Gathered in Assisi for the World Day Prayers, Basilica of St. Mary of the Angel, viewed 27 October 1986, from http://www. vatican.va/holy father/john paul ii/speeches/ 1986/october/documents/hf jp-ii spe 19861027 prayer-peace-assisi-final en.html

Race, A., 1983, Christians and religious pluralism, Orbis Books, Maryknoll, New York, NY.

Rahner, K., 1983, The practice of faith: A handbook of contemporary spirituality, Crossroad, New York, NY

Rahner, K., 1966. Theological investigations, vol. 5, pp. 118-120, Darton, Longman \& Todd, London.

Rida, M.R., n.d., Tafsir al-Manar, vol. 3, Dar al-Ma'rifah, Beirut.

Roberts, J.J.M., 1982, 'Isaiah in Old Testament theology', Interpretation 36(2), 130-143. https://doi.org/10.1177/002096438203600203

Schmitt, J.J., 1986, Isaiah and his interpreters, Paulist Press, New York, NY.

Skinner, J. \& Elmslie, W.A.L., 1946, Isaiah XL-LXVI, Cambridge University Press, Cambridge.

Smart, J.D., 1965, History and theology in second Isaiah, a commentary on Isaiah 35 40-66, The Westminster Press, Philadelphia, PA.

Tracy, D., 1975, Blessed rage for order: The new pluralism in theology, Seabury, New York, NY.

Vorgrimler, H., 1986, Understanding Karl Rahner: An introduction to his life and thoughts, SCM Press Ltd., London.

Wahiduddin, 1990, 'Islam and diversity of religion', Islam and Christian-Muslim Relations 1(1), 3-11 (Published online: 18 Apr 2007: 3-11).

Westermann, C., 1969, Isaiah 40-66, a commentary, The Westminster Press, Philadelphia, PA.

Wessels, Anthonie, 1995, 'Some Biblical Consideration Relevant to the Encounter Between Traditions,' Y.Y. Haddad and W.Z. Haddad (eds.), Christian-Muslim Encounters, University Press of Florida.

Young, Frances, 1977, 'A Cloud of Witness', in J. Hick (ed), The Myth of God Incarnate, SCM Press, London. 